\title{
DULCE Maria Cardoso E JÚLIA NERY: \\ OLHARES EM TORNO DA DIASPORA PORTUGUESA EM FRANCA E ÁFRICA
}

http://dx.doi.org/10.11606/issn.2175-3180.v13i24p107-132*

Por Alleid Ribeiro Machado ${ }^{\mathrm{I}}$

Em dezembro de 2013, mais precisamente entre os dias 12 e 13, encontrei-me com duas autoras portuguesas de grande relevância para a literatura portuguesa contemporânea: Dulce Maria Cardoso e Júlia Nery. A motivação para esse trabalho se deu, sobretudo, pelos estudos de pósdoutoramento em Literatura Portuguesa, que estou realizando junto ao Departamento de Letras Clássicas e Vernáculas da Faculdade de Filosofia, Letras e Ciências Humanas da Universidade de São Paulo, com financiamento da Fundação de Amparo à Pesquisa do Estado de São Paulo (FAPESP) e com a supervisão da Profa. Dra. Marlise Vaz Bridi.

O tema das entrevistas, resumidamente, esteve ligado ao meu projeto de pós- doutoramento, intitulado Narrativa contingente: mal-estar e exílio em O retorno, de Dulce Maria Cardoso (2013) que prevê, em alguma de

\footnotetext{
* Publicada originalmente na revista Desassossego, v. 6, n. 12, dez/2014:

https://www.revistas.usp.br/desassossego/issue/view/6986

DOI original: https://doi.org/10.11606/issn.2175-3180.v6i12p95-119

I Universidade de São Paulo, São Paulo, Brasil.
} 
suas instâncias de análise, a partir de uma perspectiva comparatista, um diálogo entre O retorno (2012) de Dulce Maria Cardoso e o "romance de estreia" de Júlia Nery, publicado em 1984: Pouca terra... poucá terra. ${ }^{1}$ Tal diálogo pode ser estabelecido por meio de questões que são comuns aos dois romances, tais como diáspora portuguesa, migração, crise de nãopertencimento e mal-estar.

A conversa com Dulce Maria Cardoso ocorreu numa quinta-feira, dia 12 de dezembro, num ponto bem tradicional do Rossio: a Pastelaria Suíça, por volta das $16 \mathrm{~h} 00$. Ali, tomamos chá, comemos umas torradas, pataniscas, pastéis de nata e outras iguarias. Sobretudo, conversamos longamente acerca dos livros de Dulce Maria Cardoso. Mas não apenas. A conversa transcendeu para os fatos da realidade circunstanciada pelo cotidiano caótico das cidades, das vidas, dos sentimentos. A ideia da entrevista era abordar, por um lado, cada um dos romances publicados da autora e expandir para questões que, por meio de análise, percebi serem traços comuns e/ou pertinentes a eles. Por outro lado, o objetivo central era focar a conversa no objeto principal de análise proposto no projeto de pósdoutoramento supracitado, ou seja, no romance $O$ retorno.

Assim, Dulce Maria Cardoso, muito à vontade e afetuosa, falou acerca das forças motrizes que conduzem o seu trabalho, de suas motivações e inquietações. No fundo o que se pode perceber ou mesmo comprovar é que quando estamos diante dessa autora, estamos, antes, diante de uma pessoa altamente sensível e comprometida com as causas sociais que envolvem a sociedade da qual faz parte. Para ela, é impossível passar diante de uma injustiça social, por exemplo, saber que diante de si há um sem-abrigo, e ter de virar as costas para o sofrimento dele, para o descaso, para o abandono. Dulce Maria Cardoso é uma mulher que transforma o sentimento de mal-estar em ficção, por meio de inverdades que, ao fim, são a melhor forma de expor as verdades mais cruéis de nosso tempo.

Já a conversa com Júlia Nery, autora e amiga, com quem trabalho desde antes do início de meu mestrado em Literatura Portuguesa, em 2003, foi realizada na sexta-feira, dia 13 de dezembro, na Quinta da Pedra Bonita, a residência da autora, localizada no povoado de Murches, freguesia de

\footnotetext{
${ }^{1}$ Em nosso projeto, prevemos um diálogo crítico secundário entre $O$ retorno em face de outros dois romances: Pouca terra... poucá terra (1984) de Júlia Nery e Livro (2012) de José Luís Peixoto, uma vez que estes dois últimos livros tratam de temas comuns à narrativa de Dulce Maria Cardoso, tais como diáspora, crise de não- pertencimento e mal-estar.
} 
Alcabideche que pertence ao concelho de Cascais. Lá, diante de uma lareira muito generosa e acolhedora, pude dar cabo à saudade, já que não nos víamos desde junho de 2011. Júlia Nery esperou-me não apenas com mimos e com uma mesa de Natal à portuguesa, mas com toda a generosidade que lhe é muito particular. $O$ foco da entrevista era a emigração em França da década de sessenta e a atual diáspora portuguesa, muito mais híbrida, sobretudo motivada pela saída recente de muitos jovens portugueses, na casa dos vinte anos, como bem lembrou a autora, para outros países da Europa ou mesmo da América.

A autora fez questão de ressaltar que a vocação portuguesa para o novo, para o desconhecido, para as viagens, ou, em outras palavras, para a diáspora, é um sentimento (basta lembrarmo-nos de um Eduardo Lourenço) bastante pertinente ao povo português desde a época da expansão marítima. Para Júlia Nery, a motivação para a debandada dejovens de Portugal, atualmente, é que mudou. Há hoje, genericamente falando, um ranço de decepção com a crise econômica que assola o país e, como se isso já não bastasse, a falta de investimento do governo em trabalho para os que "pensam", nas palavras da autora, faz com que jovens qualificados, recém-doutores, deixem seu país e sigam em busca de oportunidades em outros países. Durante a entrevista, Júlia Nery lembrou o fato de que as questões sondadas em seu livro de estreia, tão pertinentes e presentes num país vocacionado para as viagens desde o século XVI, podem ser novamente conferidas em seu mais recente romance: Da Índia com amor: a extraordinária e desconhecida aventura das mulheres portuguesas na Carreira da Índia (2012).

As duas entrevistas estão publicadas na íntegra, com pequenas adaptações na transcrição da linguagem oral para a escrita, com intuito apenas de facilitar a compreensão dos leitores. Espero que este trabalho possa ser um contributo, especialmente para os estudantes de Literatura Portuguesa Contemporânea, assim como para aqueles que admiram e são leitores dos romances destas autoras tão presentes no cenário das letras portuguesas de nosso tempo. Vale ressaltar que, ao fim das entrevistas, as duas autoras falaram sobre seus projetos futuros e próximas publicações, se bem que, no caso de Júlia Nery, houve um pedido de confidencialidade, por isso, a parte relacionada aos seus projetos futuros não constará nesta publicação.

\section{DULCE MARIA CARDOSO}


ALLEID RIBEIRO MACHADO: Tendo em pauta principalmente os seus três primeiros romances: Campo de sangue, $\mathrm{O}$ chão de pardais e Os meus sentimentos, a sua produção narrativa revela, por meio da palavra literária, um mundo ficcional que, ao fim, diz respeito ao nosso mundo caótico, desestruturado, instável, muito representativo daquilo a que vulgarmente convencionou-se chamar de pós-modernidade. Nesse sentido, como você caracterizaria, de um modo geral, as suas personagens?

DULCE MARIA CARDOSO: Como eu as caracterizaria? Para mim são como amigos. São meus amigos, eu conheço-os profundamente. Ou seja, para mim as personagens não são uma invenção, que eu vou escrever um livro e depois tenho de inventar ali umas pessoas, sabe? Eu vou conhecendo lentamente as personagens. Tenho primeiro uma ideia para um romance, geralmente do tema, depois começa a procura das personagens. E isso pode demorar anos. Pode demorar anos até eu perceber quem é que vai contar aquele livro. A Violeta ${ }^{2}$ andou anos comigo. Ou pode ser o contrário - a Violeta andou anos comigo sem eu saber onde é que ela iria entrar.

ARM: A Violeta de Os meus sentimentos é uma personagem incrível...

$D M C$ : A Violeta é tão excessiva, não é? E eu não percebia porque que aquela mulher gorda, tão excessiva... tão...

ARM: Aquele quadro de Botero? (risos)

$D M C$ : Exato. E depois percebi que era aquele romance, que era a vendedora de ceras, enfim, que era um romance sobre a memória. Mas, ainda hoje é assim, eu ando cheia das personagens, quer nos romances ou nos contos eu conheço-os todos.

ARM: Portanto, elas são íntimas para você, que as conhece nesse processo de criação ficcional, e não necessariamente como parte do real.

2 Protagonista de Os meus sentimentos, 2005. 
$D M C$ : Não, não são parte do real. São meus amigos imaginários (risos). Mas há sempre, ou quase sempre, uma brincadeira com o real. Ou seja, por exemplo, o Rui ${ }^{3}$. Houve de fato um Rui real que não tem nada a ver com o Rui do livro. Houve um Rui real, que perdeu os irmãos, que foram assassinados. E escolher uma personagem masculina e chamá-la de Rui no livro foi uma forma de homenagem, não só àquele Rui, mas ao que aquele Rui representava. Pronto, há sempre brincadeiras, por exemplo, a Maria da Guia ${ }^{4}$ que é a empregada. Houve mesmo uma empregada de uma vizinha, que eu nunca a conheci sequer, mas que eu sempre escutava a chamarem por Maria da Guia. Há brincadeiras em que eu sei porque aquela personagem é assim, ou de outro jeito. Mas só eu faço parte do real. Só eu sou a personagem real (risos). Há contos em que eu sou mesmo a personagem, em que eu estou lá. Agora, por exemplo, estou a acabar uns contos para a Bélgica e para a Holanda e eu sou eu através das personagens, mesmo a Dulce escritora. A única que éreal.

ARM: Que leitores você busca atingir com a sua escrita?

$D M C$ : Todos. Eu costumo dizer que eu escrevo para quem sabe ler. E não é saber ler tecnicamente. Quem não seja analfabeto, que consiga ler. A coisa que mais meagradou n'O retorno, aqui em Portugal, foi o fato de ele ter sido de abrangência muito transversal: foi lido por pessoas que nunca leem romances; foi lido por pessoas que nunca haviam lido romances; como foi lido por acadêmicos. Isso é a minha maior vitória em relação ao livro. Eu sei que a arte é um entretenimento da elite, não é? Como o entretenimento por si só é do povo. Como aqueles programas de televisão voltados para o povoque os intelectuaisem geral criticam. A artenão é mais do que isso, mas para uma elite que tem mais escolha, mais informação. O meu objetivo é tornar o menos possível o meu trabalho elitista. Eu nunca faço referências, quer dizer, raramente faço referências que quem não tiver conhecimento não consiga entender. Não me interessa a metaliteratura. É por isso que não me interessa excluir, meu objetivo é exatamente o contrário: é incluir o maior número de pessoas. Por exemplo, não criaria uma personagem Ulisses baseada no Ulisses de James Joyce porque, fora os acadêmicos,

\footnotetext{
${ }^{3}$ Protagonista d'O retorno, 2011.

${ }^{4}$ Personagem de Os meus sentimentos, 2005.
} 
poucas pessoas o conhecem, não é? A escrita é uma forma de comunicação e me interessa atingir o maior número de pessoas.

ARM: Talvez por isso você fale tanto de pessoas e de sentimentos?

$D M C$ : Isso é porque eu acho que não há nada mais do que isso (risos). Há, claro, a natureza com toda a sua beleza, mas que é relativamente estéril se não for apreciada. Veja, o que se pode fazer com a beleza?! O que nos prende, o que nos intriga, o que nos apaixona, são as pessoas, pelo bem ou pelo mal, ou porque nos surpreendem, ou porque gostamos delas, ou porque não gostamos delas, ou porque não as percebemos. E cada vez é mais assim. Por exemplo, eu posso conhecer o Brasil, quase todo, sem nunca lá por o pé, através do google maps. Eu posso fazer percursos, saber de tudo, ter acesso a todas as informações do país, mesmo sem sair de casa. Mas para eu saber do meu vizinho, eu tenho de perder imenso tempo, porque nós, os humanos, somos os últimos mistérios, cada um de nós, somos um continente. É tão assustadora aquela pessoa que comete um crime, por exemplo, um vizinho que fica doido e mata não sei quantos, ou uma senhora que era tão feliz e, de repente, tem um amante. São sempre surpresas. Nós não imaginamos o que vai dentro da cabeça das pessoas.

ARM: A partir da leitura, principalmente, de Campo de sangue, Os meus sentimentos e $O$ chão de pardais, ficamos fortemente impressionados com as vozes narrativas que são impostas por uma tônica feminina. Você se considera simpatizante das causas feministas e/ou de gênero?

$D M C$ : Eu devo dizer cá que a minha resposta mudou d'alguns anos para cá. Eu dantes responderia imediatamente que não. Pelo menos, desde que eu me conheço, eu sempre percebi que era diferente ter nascido mulher. Isso porque meu pai, que era um homem nascido em Trás-os-Montes, em 29, com a quarta classe, sempre me disse que eu tinha de estudar para não depender de nenhum [sic] homem. Que a pior coisa que poderia acontecer era depender de nenhum homem. $\mathrm{E}$ isso era absolutamente revolucionário vindo duma pessoa nascida numa aldeia em Trás-os-Montes, com poucos estudos. Portanto, eu sempre percebi que havia qualquer problema na condição feminina - porque o "não podes depender" soava como que se o normal fosse depender de um homem. E, depois, quando comecei a estudar, 
eu era boa aluna, ele queria que eu fizesse Direito, e ele dizia "que pena que nasceste do lado errado" - o lado errado era não ser homem, pois o mundo seria muito mais simples. Formei-me em Direito por causa dele. Era como se fosse um desperdício de capacidade que se dava por causa da condição. Mas eu nunca deixei de fazer alguma coisa por ser mulher, quando eu era criança subia às árvores mais depressa do que qualquer rapaz e também atirava pedras com mais pontaria do que qualquer rapaz, portanto, tudo aquilo que era relativo ao masculino ou ao feminino nunca fez muito sentido, talvez por não ter me apercebido disso. Quando comecei a publicar, percebi que a literatura ainda pertence a um não pensar masculino. É um mundo ainda formado por homens e as mulheres são as leitoras, e há na leitura e na escrita uma instituição, portanto, as mulheres naturalmente procuram mais os livros dos homens e respeitam mais os livros dos homens. Os homens, por seu lado, também porque estão habituados a que a literatura seja um pensar feminino, ouvem-se mais uns aos outros. É muito complicado as mulheres deixarem de ser um adorno. E eu, mesmo assim, achava que, com muito trabalho, conseguia-se. O que me fez mudar foi quando fui a uma conferência na Argélia, em Argel, e estava num café, estava a sorrir e veio um homem dizendo que eu não podia mostrar os dentes, porque não estava tapada, não tinha a burca. E, depois, ele também disse que eu não podia fumar, e eu na altura fumava. Isto foi tão humilhante, vir um desconhecido e dizer-me que não podia mostrar os dentes e que não pode fumar, que eu percebi, naquele exato momento, que apesar de eu ter um passaporte europeu, ser europeia, basta sair desta redoma e eu sou confrontada com uma condição que eu desconhecia, que é a de ser mulher. Por ser mulher não posso sorrir e fumar, por exemplo. A partir daí eu tive outra consciência. Agora o que acontece é que eu devia desde sempre o meu papel enquanto escritora, e o meu papel enquanto cidadã. Eu não acredito muito na literatura de combate. Eu não acredito muito nisso, porque acho que o sítio certo para isso é a política e a política devia ser a mais nobre das artes. Portanto, eu, se me entrevistam, enquanto cidadã prefiro falar disso em termos políticos, porque é assim que me interessa. Em termos literários, a mensagem estará lá, evidentemente, mas terá de estar muito, muito bem embrulhada, porque senão, nem uma coisa nem a outra. Eu, quando quero falar disso, faço um ensaio. Por exemplo, eu sou uma grande defensora dos outros animais. Preocupo-me imenso com o sofrimento dos outros animais, de vez em quando escrevo 
diretamente sobre isso. Mas, por exemplo, n'O retorno, o que me agradou mais, agora estive em Itália onde $O$ retorno saiu, e tudo correu muito bem, foi o fato de uma senhora chorar por causa da Pirata ${ }^{5}$, ela queria saber se alguém ficou a tomar conta da Pirata: "a Pirata salvou-se?", e isso foi muito bom, porque, de repente, era aquela cadelinha que foi abandonada... e houve alguém que ficou a pensar nela. Talvez alguém que tenha acesso ao livro fique a pensar antes de abandonar um cão. Porque fico com a consciência de que as vítimas não param de correr atrás de nós, não é? Nós é que paramos de olhar para elas... Mas isso, por exemplo, claro que isto está lá não por acaso... evidentemente que eu pensei nisso, evidentemente que eu pensei. A estética sem a ética não me interessa nada. Portanto, todos os meus livros, todo o meu trabalho, e os meus romances são o meu trabalho, é orientado nesse sentido. Não me interessa escrever bonito, não me interessa criar emoção. Se eu não tiver uma proposta de reflexão, se eu não perceber o que é que isto pode ser perigoso, o que é que isto aqui pode nos vitimar, isso não me interessa. Só me interessa quando a estética serve a ética. Ainda que eu não seja moralista nem queira convencer ninguém, porque acima de tudo eu quero que as pessoas tenham prazer no ato da leitura. Eu, por exemplo, fiquei muito chocada com a queda da ponte de Entre-os-Rios. ${ }^{6}$ Achei aquilo terrível. Primeiro, por causa das circunstâncias, pois estavam todos avisados que aquilo estava a cair, depois, porque as vítimas eram pessoas muito pobres. Eram pessoas do interior que pouco mais tinham do que ver as amendoeiras em flor. De repente, vão ver as amendoeiras em flor e a ponte cai. Para o azar deles. Não lembro qual canal de televisão estava a cobrir a notícia, mas isso pouco importa e, durante semanas, aqueles corpos a boiar, quer dizer, eram os pertences, sapatos, não os corpos. Durante semanas massacraram os familiares de quem havia perdido pai, mãe, irmãs etc. com perguntas. Depois aquilo deixou de ser notícia, deixou de emocionar e acabou-se. Passado anos, eu percebi que já ninguém sequer tinha consciência de que tinha caído uma ponte e que tinha morrido muita gente. Então, quis escrever o conto que se chama Não esquecerás e tive imensos problemas éticos, porque eu pensei isso é uma matéria tão

\footnotetext{
${ }^{5}$ A cadelinha da família de Rui.

${ }^{6}$ A Tragédia de Entre-os-Rios, como também ficou conhecido esse acidente lembrado por Dulce Maria Cardoso, ocorreu em 4 de março de 2001, por volta das 21h15, consistindo no colapso da Ponte Hintze Ribeiro, inaugurada em 1887, que fazia a ligação entre Castelo de Paiva e a localidade de Entre-os-Rios. Do acidente resultou a morte de 59 pessoas, incluindo os passageiros de um autocarro e três carros que tentavam alcançar a outra margem do rio Douro.
} 
emocionante que, evidentemente, isso só tem que emocionar. Como é que eu me torno responsável por isso? Como é que eu lhes faço justiça ao invés de agredi-los outra vez? E a única maneira que eu encontrei foi obter aquele começo e por eu e o leitor dentro do autocarro. Se eu não estivesse dentro do autocarro com o leitor e, se eu não me sentisse igualmente responsável, aquilo não faria sentido nenhum. A opção não era só expor o sofrimento. Eu não tenho esse direito.

ARM: Em Campo de sangue, por exemplo, temos quatro narradoras que, ao contarem as suas histórias de vida relacionadas a um único homem: miserável, "com unhas de cão", que vive de aparências, revelam-se não suas vítimas em comum, mas, antes, protagonistas que organizam, por suas vozes, as peças de um quebra-cabeça que tem por desfecho o silêncio sepulcral daquele que se fazia opressor. Essas personagens femininas de alguma forma vislumbram um novo comportamento da mulher portuguesa na contemporaneidade?

DMC: Não. Eu não penso assim. Eu não penso em termos de homem e mulher, sinceramente.

ARM: A questão não é gênero, a questão é o ser humano?

$D M C$ : Sim, a questão é saber como é que nós existimos, o que é que nos faz agir, porque é que temos medo. Acima de tudo, se houver alguma coisa ou algum fio condutor no meu trabalho é sempre o mesmo: o sofrimento. Esse é o fio condutor de meu trabalho e de minha vida também. É perceber onde está o sofrimento, porque nós já estamos tão anestesiados e já somos tão privilegiados que na maior parte das vezes nem se quer nos damos conta. Nós vemos um sem-abrigo, isso é uma irrealidade! Nós temos uma constituição que diz que qualquer ser humano tem direito a ter uma casa e, depois, há uma pessoa na rua. Isso não pode acontecer. Isso me incomoda muito, muito. Agora, eu não posso, eu nem sequer consigo... aquela conversa: "converse com ele um pouquinho, dê-lhe uma moedinha". Eu não consigo fazer nada, porque eu só tenho duas coisas a dizer a um semabrigo: a primeira é "desculpe, porque sou cúmplice de um Estado que permite isto"; e a segunda é "venha comigo", mas isto é uma coisa que eu não posso, nem quero fazer. A única solução era eu dividir tudo o que tenho 
até eu mesma ficar sem-abrigo. Essa seria a única solução possível. Então, o que é que eu faço? Eu não faço nada, mas nunca os esqueço, ou seja, eu nunca deixo de trabalhar e de pensar que eles existem.

ARM: Desde a publicação de seu primeiro romance, Campo de sangue, percebemos um sentimento de mal-estar a acompanhar as personagens. É como se cada protagonista de seus romances carregasse consigo as marcas de um não-pertencimento, atingindo o ápice com Violeta, de Os meus sentimentos. Essa lenta gestação parece culminar na construção da personagem Rui, d'O retorno. Poderia nos falar acerca deste sentimento de mal-estar?

$D M C$ : Se formos minimamentelúcidos, não poderíamos deixar de sentir esse mal-estar. Quem seja minimamente lúcido tem de perceber cá que há coisas que não funcionam. Quer dizer, e isto é numa Europa, ou num mundo ocidental. Há muitas franjas que não estão bem aparadas. Então, se sairmos desta redoma, como há bocado você disse, então é muito pior, não é? E nós temos que passar por este mundo. Eu, por exemplo, sou uma pessoa que tenho prazer em coisas muito simples, por exemplo, andar num parque, eu sou muito feliz a andar num parque, eu sou muito feliz a ver o mar, eu sou muito feliz a olhar para uma planta, eu sou muito feliz nessas coisas. Só que eu não posso confundir isso, eu não posso confundir a beleza que me está acessível ou o bem estar que me está acessível com o que de errado se passa. Eu não posso fazer isso. E, portanto, ser minimamente lúcida, ainda que eu seja uma pessoa muito feliz a dar um passeio num parque, é perceber que eu só sou muito feliz ao fazer isso, porque eu estou alimentada, aquecida, porque eu tenho alcançado mais ou menos os meus objetivos etc. Se eu tivesse fome, ou uma dor qualquer, já não sentiria prazer em quase nada. A fome é uma dor imensa. O não ter casa é uma dor terrível. Como é que se pode exigir a uma pessoa que não tem o mínimo, que não consegue alimentar os seus filhos, que tenha prazer a ler, que tenha prazer a ver o mar? Isto é uma abstração burguesa. Quer dizer, ver o mar é uma coisa gratuita, por que os pobres não vão ver o mar? Porque é preciso uma disponibilidade para a beleza e essa disponibilidade vem de um bemestar. Basta que se tenha uma crise de fígado que já ninguém quer ver mar nenhum (risos). 
ARM: Eu sinto esse mal-estar no Brasil, porque a desigualdade social é muito grande.

$D M C$ : Eu digo sempre que eu teria muito dificuldade de viver no Brasil por causa da assimetria social. E me parece que as pessoas já nem se dão conta, não é? Uma vez no Rio, em 2005, houve uma senhora, que já não me lembro do nome, que me ofereceu boleia para a Bienal. Ela tinha uma casa de cobertura, assim uma coisa muito bonita, maravilhosa, então ela me disse que me buscaria ao hotel. E ela foi me buscar ao hotel com uma limusine e um motorista - ela tinha tantos motoristas que mal sabia o nome daquele que estava a dirigir - confundia- se: "Ah é o Jorge! Não, não é o Jorge, é o Afonso. Não, o Afonso é o das quartas. Ah! É o que faz as folgas" (risos). Então, nós íamos para a Bienal, e eu ia naquela limusine e pelo vidro eu via as favelas. E, a certa altura, eu disse assim: "o que a senhora acha das favelas?", e ela disse-me assim: "ah, não se preocupe, elas não descem" (risos), como seu eu estivesse assustada (risos), e eu disse: "não, eu não estou com medo. Estou a perguntar como é que convive com isso, como é que a senhora convive com isso, tendo este carro, com a ideia de que há ali pessoas que possivelmente não tem o que comer!". Então ela disse: "ah não, elas estão lá e nós estamos cá". Era o "lá" e o "cá". E eu disse: "pois, mas elas podem descer um dia; a fome e a pobreza são desesperantes, mas cedo ou mais tarde as pessoas se revoltam". E ela disse: "não, não, quando isso acontecer nós pagamos à polícia". Quer dizer, a polícia continua a mantêlos lá. Portanto, era uma questão só de dinheiro. A questão é que sempre há um cá e lá, completamente dividido, não é? É uma alienação! E isso é muito que as pessoas pensam e é também por isso que as coisas não mudam. Por exemplo, sendo eu heterossexual, eu tenho quase um dever de falar sobre os homossexuais. Por quê? Porque faz parte quase sempre da maioria o esforço de integração. Os homossexuais, ao fazerem a literatura gay etc, o que fazem é uma literatura de combate, que muitas vezes não é eficaz. Porque lá está aquele a falar do assunto dele. Tem que ser eu, que não tenho nada que ver com o assunto, neste esforço de normalização. A mesma coisa em relação ao racismo e com todos os ismos. Portanto, o que acontece é que estas pessoas raramente tem voz. A história é contada por quem tem voz, e o poder é de quem tem voz, assim como as decisões são dos que têm voz. Veja, os hotéis aqui de Lisboa, do Estoril, em 75, estiveram cheios de retornados, de refugiados. Eu já estive lá e eu não conheço ninguém. Eu não conheço 
ninguém que diga que tenha lá estado. Ninguém fala sobre o assunto. Por quê? Houve milhares de pessoas que estiveram nessa situação. As pessoas têm vergonha, com isso não há registro. As minhas colegas todas não estudaram, os pais não tinham dinheiro para que elas estudassem e, depois, elas próprias começaram a trabalhar muito cedo para conseguir algum dinheiro porque faltava tudo.

ARM: Por que há esse sentimento de vergonha nos retornados?

$D M C$ : Porque aqui há. Por que era uma altura em que não ter casa era uma indignidade, e uma casa é, digamos, o reduto mínimo da dignidade. Os que ficaram em hotéis eram mal vistos inclusive entre os próprios retornados. Eu fiquei em um hotel por dois anos, no Estoril, num hotel de quatro estrelas, não eram cinco estrelas (risos). E eu também estava, a quando nada, a nunca ter voz. Quer o nível social de meus pais, quer toda a minha experiência seriano sentido de perder, como os meus colegas, ou que não estudaram, ou que se envolveram com drogas e, mais tarde, morreram por overdose, ou como os que sobreviveram, que se tornaram balconistas, ou estão casados e têm muitos filhos, muitos problemas. Ninguém pensa sobre isso. E não é estranho que durante 30 anos ninguém tenha falado sobre isso e aposto que, mesmo daqui a 30 anos, continuarão não falando, porque não vai haver quem queira. Há uma elite que não passou por isto e quem é que fala? Quem é que tem voz?

ARM: Até que ponto podemos considerar $O$ retorno muito mais ficção do que a realidade? Ou seja, que o que está lá, na verdade, seja a essência da experiência que você viveu, mas de uma forma ficcionada.

$D M C$ : Sim, eu digo sempre, em relação à ficção, que é necessário inventar uma mentira para contar uma verdade. Eu acho que a verdade, na maior parte dos casos, é longa, é maçadora, é monótona, e não se consegue ir a lado nenhum contando a verdade. E por isso a grande vantagem da ficção. $\mathrm{Eu}$, por exemplo, fiz uma versão [d'O retorno], em que o pai vinha com eles ${ }^{7} \mathrm{e}$ eu percebique desta forma ninguémiria conseguir relacionar a perda, porque ninguém consegue perceber o que é perder um país. Oque é perder um país?

\footnotetext{
${ }^{7}$ Referindo-se a uma versão que havia pensado para O retorno, em que o pai de Rui retornaria para Portugal juntamente com sua família.
} 
Normalmente as pessoas não perdem um país. Agora perder um pai, ou a Pirata, deixar um pai para trás, haveria mais gente. Portanto, tem que se inventar. Nada daquilo aconteceu de fato, eu nunca tive um cão em Angola. Aquilo que as pessoas mais se identificam eu nunca vi se quer, nunca tive acesso. Agora, eu tive acesso ao resto todo, a perda, a ela própria.

ARM: E como fica a questão da identidade? Mesmo que você tenha ido para lá ainda pequena, você se construiu lá. Depois, retornou. E se reconstruiu aqui. Como fica a questão do sentimento de nãopertencimento? Ou você não vivenciou essa angústia?

$D M C$ : Isso é algo que se nota nos meus trabalhos. Eu não pertenço. Eu não sinto que pertenço a lugar algum. Nem a lugar algum, nem a grupo algum, nem a modeloalgum. Eisso talvez seja a grande vantagem. Durante a minha adolescência eu quis pertencer, eu me esforcei desesperadamente porque precisava pertencer. E, depois, por razões várias, eu nunca pertenci. Nunca me foi dado esse privilégio. Até que eu percebi que não tinha mal em não pertencer. E diante desta vantagem, eu não estou preocupada com o pertencer, nem a um país, nem a um grupo, nem a um modelo. E posso completamente mudar de romance para romance e não estou nada preocupada com o que vão achar. Agora vou publicar uma coletânea de contos que se chama Tudo são histórias de amor e disseram: "ai isso é muito... com um título muito..." e eu não ligo nenhuma. Eu não quero saber se há pessoas cá que me acham uma "Barbie", porque agora pintei o cabelo de loiro, tanto me faz. Essa é a grande vantagem dessa experiência - quando se começa muito pequena a não pertencer, e querer pertencer, e depois se percebe que não há vantagens nisto... eu sou muito livre nas minhas decisões e não faço nada para agradar. Claro que eu me vigio porque sei que estou sendo vigiada, mas não deixo de tomar a decisão que acho que tenho de tomar.

ARM: Rui partilha um sentimento de inadequação muito ligado ao fato de se sentir estrangeiro quer em Luanda, sua terra natal, quer em Portugal, terra de seus pais. Você considera esse sentimento ainda muito comum nas gerações de portugueses retornados? 
$D M C$ : Não direi que haja esse sentimento. O que eu acho é que as pessoas que são excluídas de um modelo vencedor de uma sociedade acabarão todas por ter esse desconforto, porque não podem adquirir a imagem, digamos, de felicidade que é vendida pela sociedade. E toda a gente que não se enquadra a essa imagem fica triste, por não pertencer. Nos retornados é a mesma coisa nesse sentido, e como tiveram menos acesso porque lhes fora imputado o acesso. Mas não acho que isso tenha sido uma coisa interiorizada e verbalizada. Eu acho que a maior parte dessas pessoas ficou tão ocupada em ganhar a vida que nem sequer pensaram. Isso é um privilegio das segundas gerações, como eu, que já não passei por isso, ou seja, e, depois, é também um privilégio de quem tem memória.

ARM: Talvez a Violeta tenha vivido muito isso, não? Essa questão de nãopertencimento, de inadequação, assim como o Rui...

DMC: Sim, é verdade. Assim como o protagonista de Campo de sangue. E, no casodele, aindaé outra coisa, porque ele é um homem branco, quer dizer, é o contrário disso tudo, ele ali no esforço de "pertencer". Para mim sempre foi muito clara a ideia do pertencer e do não-pertencer, isso sempre esteve muito presente: que parte da identidade temos de sacrificar?

ARM: Que diálogo você quer travar com o presente trazendo à tona a história da Guerra Colonial e da difícil situação vivida pelos portugueses em África?

$D M C$ : O passado tem a vantagem de não existir em lado algum, eu sempre costumo dizer isso. Não tem grande importância. O importante é perceber quem somos, quem fomos. Saber quem fomos ajuda-nos a perceber quem somos e, mais do que isso, ajuda-nos a saber o que queremos ser. E o passado por si só, mesmo na questão do retorno, não me interessa. Aquela coisa de saber só o que aconteceu, como é que foi, não me interessa. Agora me interessa todas as pontes com o presente e justamente com o futuro. Interessa-me perceber que os erros podem não ser repetidos. Interessa-me, por exemplo, nós agora, neste momento, em Portugal, estamos a vivenciar um fim de ciclo tão grave como foi o fim de ciclo do império. Em 75, quando eu vim, tinha acabado o império e agora acabou o sonho europeu. Nós sabemos que a Europa não vai funcionar e não está a funcionar. Como é 
que nós saímos daqui? Talvez se nós tivéssemos percebido o que representou o fim de ciclo do império, estivéssemos mais aptos a perceber o presente. Nós nos desfizemos do império, como o prof. Eduardo Lourenço diz, como quem se desfaz de uma camisa velha. Nós fomos e tivemos, durante 500 anos, um império. Isto é muito importante para um povo, isto é constitutivo, não é? Nós não podemos, de repente, agora acordar e não termos nada e também não querermos saber o que tivemos, nem o que fomos. Nós temos com o Brasil uma relação péssima e o Brasil conosco, e nunca resolvemos nada. Nunca resolvemos a questão do colonialismo, nem a questão do pós-colonialismo. Nunca resolvemos nada. É só para o que nos convém. É só para nos culparmos uns aos outros. Só que isso não é resolver. Perguntam-me, por exemplo, "então, afinal, houve racismo em Angola?" e eu respondo: "como é que não poderia haver racismo em Angola, se em 2013 há racismo em Lisboa? Como é que em Angola, numa colônia, não haveria? Em 1974 não havia racismo? É claro que havia racismo". Agora, eu já não estou preocupada que em 74 havia racismo, mas que em 2013 continua a haver racismo. Se em 74 ou 75 tivéssemos tido consciência que havia racismo talvez agora em 2013 não houvesse tanto. Então, não resolvendo essas questões, o racismo continua. Temos medo do que é diferente. Temos medo de tudo o que é desconhecido. Uma cor de pele, uma conduta diferente, tornam-se assustadores. Se até do igual temos medo, do que dirá do que é-nos diferente? O retorno só me interessa por ter muito que ver com o recomeço. $\mathrm{N}^{\prime} \mathrm{O}$ retorno, só me interessa a perda na perspectiva do recomeço. A perda por perda não me interessa. N'Os meus sentimentos só me interessa aquele esforço todo de memória, numa perspectiva de... [recomeço], como aquela estrada de redenção que acaba numa luz final, não é? Interessa-me ir até os mais profundos dos abismos, mas desde que haja um caminho de volta, senão já chega a realidade como está.

ARM: A questão da diáspora sempre foi muito forte e imperativa em Portugal. Nesse sentido, poderíamos traçar alguns contrapontos em relação aos portugueses que foram para a África e depois retornaram e os emigrantes portugueses em França?

DMC: Vejamos. Há a questão dos argelinos em França. Eles ficaram em guetos. Eu por acaso agora estou muito curiosa. Vou apresentar O retorno 
em França e vou ver como que é recebido. Acontece que em França os argelinos ficaram em guetos, e para os retornados não houve gueto. Não foi a metrópole que quis que os retornados voltassem, os retornados quiseram voltar, então, de alguma forma, cada retornado apagou de si as marcas, as cicatrizes do que foi e recomeçou como fosse de cá. De alguma forma, nós abdicamos de nossa identidade enquanto grupo para nos diluirmos. Já em relação aos emigrantes franceses é outra coisa. Eles vinham cá quase sempre nas férias, vinham sempre cá. Por exemplo, o dinheiro angolano, moçambicano, não valia cá, ou valia metade, o esforço era fixar as pessoas lá. Ao contrário do que houve em Angola, não houve uma política de fixar as pessoas em França, a ideia era ganhar dinheiro. Por outro lado, Portugal sabia bem dos fundos que vinham das remessas dos emigrantes. E, na altura, antes do 25 de abril, nem se punha o tanto de ouro, café ou petróleo, vindos de Angola e de outras colônias, nem se punha isso. Depois do 25 de abril, depois que se perdeu as colônias, é claro que as remessas dos emigrantes eram muito apelativas, não é? E os emigrantes eram tidos quase como heróis, porque, de alguma forma, mandavam muito dinheiro para o país, por outro lado, não havia emigrante que não passasse cá o agosto, que não viesse nas férias, vinha cá casar "a filha". Os laços continuam a ser com a terra-mãe. Depois há o problema dos filhos que nasceram lá e não querem voltar, mas esta é outra questão. É mesmo diferente de nós em África. Em África havia as cartas de chamada e a ideia era povoar aquele território, era fixar as pessoas lá.

ARM: O retorno é um romance talhado pela dor: dor pelas perdas humanas e materiais, dor pelos bens conquistados e deixados para trás, dor por futuros cortados desde a raiz. No limite, qual foi a força motriz para a (re)criação da história dos retornados?

DMC: É o recomeço. É sempre a possibilidade de recomeço.

$A R M$ : Isso é muito interessante, porque quando lemos o conjunto de seus romances, percebermos mesmo que há, sim, esperança.

$D M C$ : É preciso mesmo ser um bom leitor para se perceber isto. E não acho que se trate de uma esperança reduzida ao otimismo. Quando me dizem que uma pessoa das favelas, se quiser, pode virar um grande músico, e dá como grande exemplo do $x$ ou b, eu digo sempre que não se pode pegar nas 
exceções. A vida não é feita para exceções. Eu não posso pensar em qualquer pessoa que sofra uma injustiça, de repente vira um Nelson Mandela e fica 27 anos preso, nem qualquer mulher que é violada se torna a Ophra dos Estados Unidos, não posso pensar assim. Nem posso dizer a uma mulher que foi violada: "olha tu estás deprimida, tu estás nesta situação, mas repara que há uma que conseguiu se tornar a mulher mais rica do mundo". Essa esperança é obscena para mim. A vida foi feita para a normalidade - eu digo que não podemos viver de exceções. E é sobre a normalidade que as expectativas devem incidir. Mas é preciso se ter uma esperança lúcida.

ARM: Podemos considerar O retorno uma tentativa amiúde lúcida de se fazer comque as novas gerações conheçam cicatrizes passadas que, dentro da dinâmica do tempo, poderiam ficar para sempre guardadas num passado sem retorno?

DMC: É exatamente isso. É preciso abrir a ferida para a cicatriz ficar melhor, para a cicatriz ficar mais perfeita. O passado está lá, ninguém muda. Agora, muda-se a maneira como se olha para a cicatriz. Há muitas maneiras de se olhar para a mesma realidade. Cabe a quem pensa sobre isto, a quem quer pensar, indicar a maneira de se evitar o sofrimento, e tornar a vida mais fácil. A morte, por exemplo, não tem nada de especial, só tem para os que ficam. O problema grave, em termos de espécie, é o sofrimento. O que é que se faz com o sofrimento?

ARM: E o que podemos aguardar da Dulce Maria Cardoso para 2014?

DMC: Em outubro deve sair $O$ amante americano, mas antes, em maio, sairão histórias infantis, que foi uma encomenda da RTP. Eu não queria fazer até porque não é o meu gênero, mas por outro lado, eu gosto de sair da zona de conforto. Eles disseram que tinha de ser uma coisa baseada na bíblia. $\mathrm{E}$ eu pensei, a maior parte dos preconceitos vem exatamente da bíblia, porque nós vivemos nesse caldo judaico-cristão, não é? Então pensei, se calhar é interessante como a criança, nestes episódios, verá retirados ou resolvidos os preconceitos. Então eu fui ver alguns episódios da bíblia, por exemplo, a Torre de Babel, que é um apelo à xenofobia (risos). Portanto, esses episódios que podem ser geradores de grandes preconceitos ao longo 
do tempo, eu os peguei e, digamos, desfiz o preconceito, desfiz o nó. Eu pensei, as crianças vão ver aquilo e vão ficar com outra imagem.

\section{JÚLIA NERY}

ALLEID RIBEIRO MACHADO: Por que a autora escolheu a temática da emigração portuguesa em França para a sua estreia como romancista, em 1984 ?

JÚLIA NERY: Porque nessa época a emigração era um dos factos da vida portuguesa, que influenciava muitas famílias, e que influenciava a própria sociedade portuguesa, na medida em que havia grandes problemas, digamos assim. Por um lado, havia muitas mulheres sem marido, especialmente no interior, ficando elas com as responsabilidades da vida no campo e da educação dos filhos. Em outras circunstâncias, havia crianças que eram entregues às avós, porque os pais não podiam tê-los nos países em que estavam emigrados. Não só na economia, mas, sobretudo, na estrutura da sociedade, o fenômeno da emigração nessa época tinha muita importância, era muito marcante. E também porque eu tinha estado em França e tinha privado com muitos emigrantes que me computavam a visão que eu já tinha da emigração. Isso ocorreu também em Portugal, quando também tive oportunidade de privar com pessoas, com famílias que haviam emigrado para a França e que, por isso, me davam uma visão completa: a visão que eu havia tido em França e a que eu vim a ter em Portugal completavam-se. E eu fiquei com uma curiosidade de explorar e compreender essa questão. Há quinze dias participei de uma tertúlia e falei acerca dessa motivação, ou da realidade como inspiradora, e eu expliquei exatamente como a realidade havia motivado a escrita de "Pouca terra...". Quando eu estava em França, em 1980, com uma bolsa de estudos, fui assistir a uma conferência, em Vichy, de membros da extrema Direita, e acabei por ouvir um ferrenho discurso contra os emigrantes. Eu estava revoltada, mas não podia dizer nada, até por medo, pois estava ali sozinha. Mas na minha cabeça começou a surgir uma "leitmotiv": o português é a semente que em qualquer terra dá fruto. Eu dizia isto e parecia um refrão. Naquele mesmo dia, quando cheguei ao hotel, comecei a escrever um texto como uma espécie da catarse em torno de tudo aquilo que havia acontecido e, naquela altura, não percebi que era, na verdade, o começo do romance. Comecei a escrever o 
romance como uma resposta ao Monsieur Pen ${ }^{8}$. Tudo isso motivou a escolha das personagens. Não podiam ser emigrantes que só pensavam em voltar para Portugal com muito dinheiro. Por isso, [no livro] o pai de família ${ }^{9}$ vai andar envolvido nas lutas sindicais de 78 , a rapariga ${ }^{10}$ estuda sociologia e quer integrar-se à vida francesa, e são pessoas que pensam a vida para além da casa "muito maison". Quis escolher personagens que emigraram por motivos especiais, por "mais altos motivos", digamos.

ARM: A moderna diáspora portuguesa em França, ou seja, aquela ocorrida na década de 50 do século XX, e o consequente retorno dos emigrantes e/ou de seus filhos, parecem ser um eterno processo de reencontro dos portugueses com as suas raízes. Até que ponto o romance é uma tentativa de ressaltar o amor explícito do português à sua terra natal?

JN: Essa pergunta ébem difícil de responder porque, por um lado, temos uma família que emigra e eu não vejo em todos os membros da família esse amor pela terra natal. Na ficção, Maria Menina tinha raízes muito fortes coma sua terra, mas esse sentimento não estava tão presente nos outros membros. Repara, são três gerações que estão lá representadas, não é? A avó, que foi o motor da emigração, para que a neta viesse a ser alguém pelos estudos. Depois há um casal, que não manifestava grande amor pela terra e a filha mais nova que tem uma curiosidade muito grande e, ao mesmo tempo, sente um apelo pela terra dos pais, pela terra dela, afinal ela também nasceu em Portugal, mas esse apelo vem muito mais pela convivência com a avó, das saudades que a avó tem de sua terra, a vivenciar muito aquela tensão entre o lá e o cá. Era exatamente essa tensão que eu queria explorar. Na avó havia esse amor muito grande e na neta há a curiosidade despertada pelos sentimentos da avó.

ARM: Para nós que estudamos a literatura portuguesa, que para nós é uma literatura estrangeira e, muitas vezes, passível de generalizações, é muito importante percebemos as idealizações, como a que se diz em relação "ao amor do português à sua terra", a fim de se evitar exatamente essas idealizações.

\footnotetext{
${ }^{8}$ O responsável pelo discurso ferrenho contra os emigrantes.

9 Referindo-se a Edgar, casado com Maria da Luz, filha de Maria Menina, protagonista do romance.

${ }^{10}$ Referindo-se à Leonor, filha única de Edgar e Maria da Luz, portanto neta de Maria Menina.
} 
JN: Sim, é muito importante que se perceba isso. Como em tudo na vida, há as generalizações. Mas há certamente um amor pela terra. Veja por exemplo Joana ${ }^{11}$, ela é uma personagem que nutre um grande amor à sua terra; ela não tinha criado muitas raízes em Portugal, mas ela tinha muito amor a Portugal porque sua terra era a sua identidade, ela identifica-se muito fortemente e o amor dessa personagem é muito maior do que das outras personagens de Pouca terra... poucá terra. Para Joana, e assim como também vai ocorrer com os emigrantes portugueses em França, voltar à terra era um símbolo de liberdade. Mas, no caso de Joana, ela faz ainda uma coisa que, naquelaépoca, não era habitual, principalmente para as mulheres, que era $\mathrm{o}$ retorno: ela luta pelo retorno e consegue. ${ }^{12}$

ARM: Atualmente, os filhos (ou os netos) de portugueses em França continuam a optar por retornarem a Portugal?

JN: São os filhos e netos que estão em França. Por exemplo, a atriz de La Cage Dorée $^{13}$, a que faz o papel de cunhada ${ }^{14}$, fez uma comunicação belíssima recentemente, ela é filha de emigrantes. Em França há exemplos interessantíssimos, por exemplo, neste momento, há pessoas muito importantes em França que são filhos de portugueses, mas que nunca evocam essa condição de serem descendentes de portugueses. O filme é muito interessante porque acaba por nos remeter para uma realidade que para nós passou despercebida, ou seja, muitas portuguesas foram trabalhar como porteiras e muitas delas foram para os bairros chiques de Paris e em cada bairro há uma escola, como cá há uma delimitação, e os filhos acabaram por se beneficiar deestar em belíssimas escolase, por conseguinte, esse benefício acrescentado pelo sacrifício dos pais, possibilitou que eles acabassem por terem muito boa formação. A atriz contou um fato dum senhor que na estreia do filme, em certa cena que já vou lhe dizer qual é,

\footnotetext{
${ }^{11}$ Fazendo referência à protagonista de Da Índia com amor (2013) romance que se passa no século XVI e que conta a aventura de mulheres na diáspora portuguesa para a Índia, em meio às grandes navegações portuguesas.

${ }^{12}$ Retornar para Portugal, depois de ter estado na Índia.

${ }^{13}$ Referência ao filme A gaiola dourada (2013), de Ruben Alves, que conta a história de um casal de imigrantes portugueses na França, interpretados por Rita Blanco e Joaquim de Almeida, que a certa altura dos acontecimentos, diante da oferta de uma herança inesperada, veem-se no dilema de abandonarem o que construíram em França e retornarem a Portugal.

${ }^{14}$ Interpretada pela atriz Jacqueline Corado.
} 
chorou enquanto apertava a mão de sua mãe, porque ele viveu a mesma situação queé vivida no filme, ou seja, a mãe era porteira num bairro muito chique e ele estudou num colégio muito chique... um dia qualquer, a mãe apareceu-lhe de repente no colégio e ele se sentiu envergonhado, e há uma cena semelhante a esta no filme. E o homem, ao ver aquela cena, viu-se retratado. A emigração traz todas essas coisas, ou seja, a situação de estar em outra terra e o desejo de revanche, de mostrar que se vale alguma coisa - no filme isto está muito bem retratado.

ARM: Sabe-se que diversos portugueses decidiram emigrar em busca de uma vida melhor e de um trabalho cujo ordenado lhes permitisse realizar muitos dos seus sonhos e ambições. No romance, no entanto, percebemos que os sonhos de Maria Menina, a matriarca da família, não se restringiam ao nível econômico. O que ela desejava era ver a sua neta formada e com diploma de nível superior. Embora Maria Menina tenha lhe garantido isso, Leonor parece desejar exatamente aquilo que muitos filhos de emigrantes portugueses optaram: ou seja, por voltar a Portugal, fazendo um caminho inverso ao de seus progenitores. Concorda com essa avaliação?

$J N$ : Muitos filhos optaram por voltar, mas agora muitos netos optam por sair. E ainda há os casos dos muitos que optam por ficarem em França porque atingiram uma situação tal que cá não tem paralelo: os amigos da escola são de lá, os amigos do liceu são de lá, os colegas de trabalho são de lá, normalmente se casam lá, conforme, não direi a classe social, mas a classe cultural. E, por outro lado, há determinadas famílias, principalmente das províncias, em que as filhas continuam a vir casar em Portugal. Mas isso já não está tão marcado como há muito anos, quando vinham casar a agosto.

$A R M$ : Leonor parece encarnar os sentimentos contraditórios de quem vive a ambivalência entre um lá: a França e a segurança de acolhimento que lhe era dada; e um cá: Portugal e a incerteza de prosperidade. Embora a França tenha sido o seu país de acolhimento, Leonor vive a expectativa dessa decisão - algo que parece ter ficado em aberto no romance. Por que a autora preferiu não dar um desfecho para essa questão?

JN: Gosto de deixar os meus romances em aberto (risos). Há leitores que não gostam disso: "mas por que não fechou o romance?". Gosto de deixar em 
aberto para que a personagem tenha liberdade. Há muitos que acham que a Leonor ficou em França, outros que preferiu voltar a Portugal, que seu lugar era cá. O romance está tão aberto que o leitor pode pensar o que quiser.

ARM: Em nossa tese de doutoramento ${ }^{15}$ analisamos exclusivamente a construção das personagens femininas em suas narrativas, mais precisamente, as que alcançavam status de protagonistas. Nesse sentido, refletindo agora acerca da geração representada em Pouca terra... poucá terra pela tríade: Maria Menina, Maria da Luz e Leonor, parece-nos que, na verdade, as três estão a representar dicotomicamente faces do feminino:

- Maria Menina: mulher de força e coragem; é destemida e determinada; não estudou e tudo o que sabe baseia-se na experiência prática da vida. Permanece na aldeia, trabalhando sobretudo na terra, até a morte de seu marido, quando se vê liberta para seguir os seus sonhos e emigrar para a França.

- Maria da Luz: teve acesso ao ensino básico; consegue sair da aldeia com apoio de Maria Menina e por intermédio do casamento com Edgar. Em Lisboa, consegue trabalho e opta por uma única gravidez. Segue Maria Menina e Edgar na diáspora para França, onde consegue melhores condições de trabalho, por ter estudado.

- Leonor: jovem que teve todo o apoio familiar para estudar. Em França, fez amigos intelectuais e partilha leituras feministas. Engajou-se no movimento estudantil do maio de 68 . No entanto, o seu caminho é trilhado ao gosto dos sonhos da avó. Seu conhecimento de vida é limitado ao conhecimento teórico com que avalia o mundo.

Assim, diante do exposto, é válido afirmar que Maria Menina seria a personagem de maior destaque, enquanto Leonor seria o seu contraponto e Maria da Luz uma personagem intermediária? O que nos leva a pensar isto é o fato de que Maria da Luz não alcançou voz própria nem se insurgiu contra as limitações que eram impostas às mulheres.

JN: Maria Menina é a personagem de maior destaque. O romance era para se chamar Maria Menina e eu estou muito arrependida de não tê-lo nomeado assim. Na época quis mostrar o som do comboio... o jogo - com o sentido do pouca terra, terra pouca. Mas, ela é mesmo a raiz, a terra, a

\footnotetext{
${ }^{15}$ Tese de doutoramento em Literatura Portuguesa - MACHADO, Alleid Ribeiro. As personagens femininas de Júlia Nery: paradigmas e representações. FFLCH/ USP, 2011.
} 
sabedoria. As duas, Maria Menina e Leonor, seriam polos opostos, e uma representa o cá e a outra representa o lá. E vão trocando essa tensão, não é?

ARM: Maria Menina, que vivenciou a década de 50 do século $\mathrm{XX}$, é uma mulher que se vê amarrada aos modelos culturais de uma província para a qual o casamento por arranjo significava: "casa, pão e respeito". Ou seja, o casamento era a representação da segurança futura para aquela que, a não ser apoiada numa figura patriarcal, não teria condições de por si mesma, gerir o seu futuro. No contexto português atual, o casamento ainda é visto dessa maneira, levando-se em consideração as mulheres que ainda não vivem nas cidades e continuam nas províncias?

JN: Quando casam a Maria Menina, contrariamente à vontade dela, e o pai lhe diz: "Maria Menina, casamento é casa, pão e respeito"? Hoje depende muito da cultura, mas, em todo o caso, as mulheres da província hoje, já são muito, muito libertas, até mais do que as da cidade. Há imensos divórcios na província, há imensos casos de adultério, e quando falo da província, falo daquela que conheço, que é a Beira Alta. Há muito patriarcalismo em Portugal, sim, mas as mulheres da Beira Alta são mais libertas. As minhas férias na Beira Alta eram diferentes das da Beira Baixa. As mulheres da Beira Alta trabalhavam e praguejavam como homens, e bebiam como homens, já as da Beira Baixa eram todas recatadas, submissas. A minha ideia das mulheres da Beira Alta é exatamenteesta.

ARM: Independente do que já conversamos na questão anterior, Maria Menina é construída como uma mulher forte, capaz e determinada. Na verdade, ela é força motriz de sua família, que, após a morte de seu marido, liberta-se para enveredar pelo caminho de seu principal sonho: realizar a diáspora em França a fim de ver sua neta estudada. Se pensarmos em Leonor, representante da terceira geração, teríamos a imagem de uma jovem cujos sonhos estão sendo construídos a partir dos sonhos da avó. A autora acredita que ainda hoje os pais e avós interfiram nas decisões de trabalho e estudo de seus filhos/netos, impulsionando-os para fora dos limites de Portugal? 
JN: Hoje em dia, o que os motivam a sair é o primeiro ministro (risos) ${ }^{16}$, que disse que se cá não há trabalho pois que emigrassem. Esta vaga de emigrações foi motivada por ele que os mandou embora, que quer matar os velhos e se ver livre dos novos (risos). Só quer ficar com os que produzem, aqueles que pensam não lhe interessa muito. Ele está a privatizar tudo. $\mathrm{O}$ primeiro ministro é retornado ${ }^{17}$, fez parte daquelas pessoas que perderam o bem bom e voltaram para cá, e isso é muito difícil, não é? Agora, está a vender tudo para os angolanos. Deve deixar lá melhor, não é? Isto está um horror. Ou seja, todas as conquistas do 25 de abril - estão a acabar com todas! E o golpe final é fazerem uma nova constituição para tirar o poder do tribunal constitucional. É um retrocesso.

ARM: Há muito tempo, recolhemos numa recensão crítica uma frase dita por Júlia Nery acerca da criação de Pouca terra...poucá terra, cujo conteúdo diz: "Quis que o meu romance fosse um pequeno retrato do que neste momento somos. Somos cá e lá". Qual sentido toma essa frase hoje, quase 30 anos após a publicação do romance, levando-se em consideração que a vocação para a diáspora continua sendo uma realidade muito presente, principalmente face à atual crise econômica que vive não apenas Portugal, mas parte do resto da Europa?

JN: Ganhou muito sentido, e possivelmente por quê? Porque, nos anos 60 e depois isso refletiu nos 80/90, éramos cá e lá, cá e lá, cá e lá. Neste momento, somos um lá - cá, ou seja, as pontes da nova emigração são muito mais fracas. Antes era muito mais localizado: França, Alemanha. Hoje está muito diversificado. Se estudarmos os novos movimentos migratórios, neste momento temos portugueses instalados, jovens, por todo o mundo, [o movimento migratório] está muito mais diluído e acontece muito mais. E o mais preocupante, é que é gente muito jovem. Nos anos 60 era uma emigração feita a partir dos 30, 40 anos, agora não, é uma emigração que começa a partir dos 20. Ou seja, Portugal durante décadas, a partir de 76, investiu muito na educação e na formação, e isto está a saber agora nos cientistas que estão a aparecer, que estão a se ir embora. Foi um investimento a fundo perdido, por que quem irá se beneficiar desse investimento? Os mesmos que nos levam os juros. É uma estupidez. Mas

\footnotetext{
${ }^{16}$ Referindo-se a Pedro Passos Coelho.

${ }_{17}$ De Luanda.
} 
nós continuamos a ser um país cá e lá, aliás, desde o século XVI, como procuro mostrar também no romance Da Índia com amor (risos).

ARM: Vamos partir de algumas manchetes publicadas recentemente em jornais portugueses para formatar o teor da nossa próxima questão:

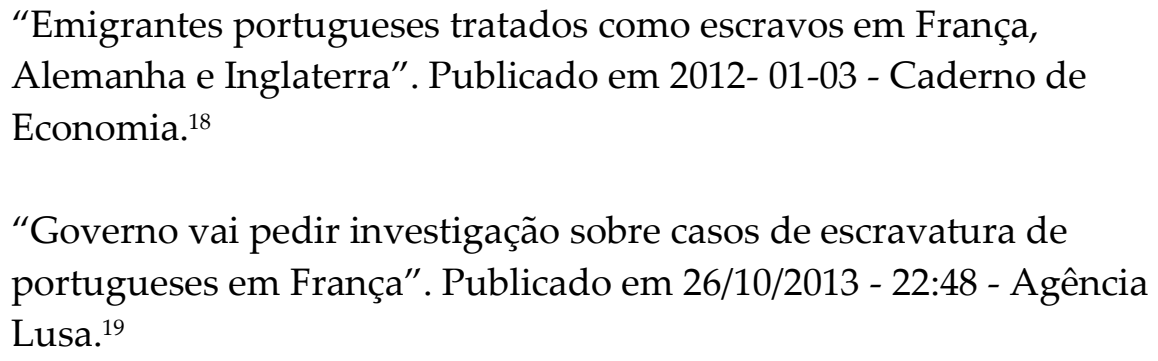

Temos por certo que uma das funções da literatura é a representação do real. Tal representação, no entanto, dada a nova ordem, indeterminada e plurissignificativa, que a linguagem literária instaura, parece captar algo presente no imaginário social, que acaba, muitas vezes, por prenunciar o futuro. Nesse sentido, há certo trecho nesse seu romance da década de 80 que é altamente prenunciador da atual crise econômica europeia. Trata-se do diálogo travado entre Leonor e sua amiga francesa Cathy, em que esta parece não acreditar que no futuro os portugueses emigrantes continuariam a ser vistos com bons olhos pelos franceses:

Não sou grande apoiante da entrada de emigrantes e inquieto-me: quando o desemprego se vislumbrar num futuro próximo, muitos franceses começarão a ver o emigrante com maus olhos e a querer pô-lo na fronteira. Pode mesmo começar uma certa forma de racismo. E depois? (NERY, 1984, p.158)

Observamos uma proposição muito antecipadora de um estado futuro que hoje é realidade! A fala final de Leonor parece estar em consonância com o passado grandioso português, ligado antes de tudo à diáspora dos descobrimentos e à habilidade do povo português de adaptação a diferentes terras, climas, povos. Vejamos outro trecho:

\footnotetext{
18 disponível em:

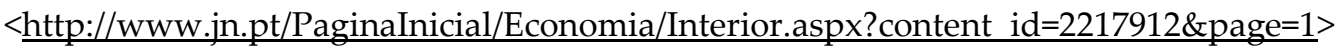

${ }^{19}$ disponível em:

$<$ http://www.publico.pt/sociedade/noticia/governo-vai-pedir-investigacao-sobre-casos-deescravatura-de- portugueses-em-franca-1610453>
} 
E depois, minha amiga francesa, nós entraremos pelo vosso sangue, pela vossa língua, pela vossa história, pelos vossos hábitos, que o português é semente que em qualquer terra dá fruto (NERY, 1984, p.161)

A resposta de Leonor à Cathy seria uma forma de autoafirmação identitária do imaginário coletivo português?

JN: Sim, porque penso que o fenômeno emigratório acaba por ter esse sumo, digamos assim, muito forte. Ou seja, eu não sei, por exemplo, interrogo-me, se o fenômeno migratório africano para Portugal, que neste momento se traduz no desenraizamento, no crime urbano, mas daqui a alguns anos se traduzirá numa influência que o próprio português vai sofrer, não é? Não sei até que ponto a cultura africana vai modificar a nossa, de tal maneira que o movimento migratório africano é muito forte. E da mesma forma o movimento migratório em França era muito forte, veja A Gaiola dourada, porque os desgraçados dos emigrantes portugueses acabam a ser os guias daqueles franceses (risos). Mas, seguramente. Gostava mesmo de saber o nível de influência mas, com certeza, entramos pelo sangue, que hoje há muita miscigenação, há muitos casamentos em França entre portugueses e franceses.

\section{Licença: (ㅇ) (1) @}

Concepção e realização da entrevista:

Alleid Ribeiro Machado

Pós-doutorado em Literatura Portuguesa pela Universidade de São Paulo. Pesquisa financiada pela Fundação de Amparo à Pesquisa do Estado de São Paulo. Doutora e mestra egressa do Programa de Pós-Graduação em Literatura Portuguesa da Universidade de São Paulo.

Contato: alleid@alumni.usp.br

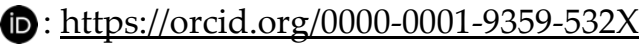

